Vol. 2 No. 1, (2021) pp 1-14.

Journal Homepage: https://sjs.journals.ekb.eg

\title{
Economic and Social Factors Affecting the Purchasing Power of Customers in Fast Food Restaurants (Applied in Marsa Matrouh City) Samar Shebl $^{1} \quad$ Dalal Abdel Hady $^{2} \quad$ Amr Abdel Hameed Refaat ${ }^{3}$ \\ ${ }^{1}$ Faculty of Tourism \& Hotels, Matrouh University \\ ${ }^{2}$ Faculty of Tourism \& Hotels, Alexandria University \\ ${ }^{3}$ Faculty of Desert \& Environmental Agriculture, Matrouh University
}

\section{ARTICLE INFO}

Keywords:

Customer purchasing power Economic factors

Fast-food restaurants

Economic circumstances

(JTHH)

Vol. 2 No. 1, (2021) pp 1-14.

\section{Abstract}

Fast food restaurants constitute a huge percentage of restaurants sector which is considered as an important sector for each country. This sector highly depends on customer purchasing power which refers to the capacity of a customer to buy certain quantities of goods and services. Hence, the purchasing power for customers and whole country is influenced by the economic factors .

The aim of this study is to understand and analyze the characteristics of customers and fast-food restaurants with the different types of work in Marsa Matrouh and the impact of the economic factors on the consumers' purchasing power .

The population of the study comprises all fast-food restaurants in Marsa Matrouh city which contains 7 restaurants and using a simple random sampling technique. A target sample of 425 customers and 7 managers was chosen, so there are two questionnaires' forms were designed .

Data were analyzed using SPSS technique and results indicated the importance of these factors and their impact on the customers' purchasing power.

The results have emphasized that economic factors are the most important factors which affect the purchasing power, behavior and customers' choices. Also, the working nature of these restaurants in that city affects their behaviors highly. The study accepts that there is a positive relationship between economic factors (consumers' income, family income and credit card acceptance) and customer purchasing power.

\section{Introduction}

Restaurants and food service industry are important for any country, which is characterized by rapid growth and continues change in people's preferences, also it is more volatile and changeable than hotels or tourist attraction types (Cronin \& Taylor, 1992). This industry is highly affected by many factors but the most important one is the economic factors. It is also called financial or monetary factors which refer, a specific definition for the study, to the factors that deal with stages of sales in the market and the financial position of the consumers, i.e. the amount of cost that individual spends in purchasing goods and services that contribute the overall sales of the company (Ramya and Ali, 2016). 
There is a serious psychological, mental and negative impacts on consumers as shoppers because individuals need to have more awareness about the economic or financial emergencies from the press, social media, internet and etc. The key to the success of the tourism and hospitality industry is nutrition and extends to the hardness of the society and its economy (Azim, 2014). Also, it is worth mentioning, there are a plenty of factors which affect the demand in general and fast food restaurants specifically, and the most important factors are personal income, family income, income expectations, savings, liquid assets of the consumer and consumer credit which affect the purchasing power of customers which means the capacity of a customer to buy certain quantities of goods and services. In general, high consumer purchasing power means customers with high incomes and purchasing power related to the supply and prices of goods available (Abd El-Hady, 2003). Marsa Matrouh is located in an economic territory which includes three provinces; Alexandria, El Behera, and Matrouh. It has a unique and special location on the Mediterranean coast about 450 kilometers along. It comprises eight cities, extends from El-Hamam city in the east to El-Salloum city in the west, which covers an area of 166.56 thousand $\mathrm{km} 2$, representing $16.5 \%$ of the Republic's total area. According to the recent statics at 26 March 2018, the population of the country has reached 446978 thousand people (Matrouh governorate \& CAPMAS, 2018, March 26). It has an enormous potential for tourism development because of its charming nature which provides a sense of safety for tourists. Its attractive sites vary from sandy beaches, calm bays, attractive and historical sites, sand hills and deep valleys which are attractive sites for Safari tourism to Marymina monastery, mass graves, military museum in El Alamein, Rommel museum, temple of Ramses II in the om alrakhm, hamam Cleopatra, Siwa Oasis which has warm sand which treats skin diseases, all of these qualify the province to be a preferred destination for tourists (matrouh.gov.eg, 2018, April 1). The city is characterized as a recreational tourism in the summer, which represents the touristic season of the city. By the nature of the city, there are many places work in the summer only like fast-food restaurants, circus and amusement park. The study emphasizes on fast-food restaurants; MacDonald's, KFC, Pizza King, Tekka, Hardees, Moa'men and Pizza Hut. This city is always chosen because of its different touristic nature which affects the working of these restaurants which work only from 1 June to 15 September and the city isn't considered as a part of scientific researchers. This study seeks to find a deeper understanding of the impact of different factors on consumer buying power in fast-food restaurants. Specifically, it concentrates on the relationship economic factors and consumer purchasing power at the fast-food restaurants (Furaiji, 2012).

\section{Literature Review}

Consumer purchasing behavior and power are huge issues which threatens the marketing and economic sectors that are distinguished by continual change. Despite the importance of this issue, it has not been adequately studied in restaurants' sector, especially fast food restaurants, although fast food has been appeared in the world economy since the last four decades. The research will focus on another side of fast-food restaurants by shedding the light on the factors that influence their consumers' purchasing behavior. As noted by Hawkins and Mothersbaugh (2015), consumer buying behavior refers to the selection, buy and consumption of goods and services to satisfy their wants so the purchasing decision is a result of many factors. Also, this research will expose the nature of Marsa Matrouh City. 


\section{Fast food restaurants}

The category of fast food restaurant includes a wide and important category of all restaurants. They are defined as the places where provides a quick customer service in a period that does not exceed ten minutes in prime time while there are other studies have classified them, according to the provided product which is prepared and cooked quickly and served in a time ranging from two to fifteen minutes. It also has a low price and easy to consume by hand or cutlery (Kouzmal, 2009). They appeared in America, specifically in 1920, as a result of the appearance of modern technological devices in the conserving and handling the food sector, As a result for the increase of cars' numbers, the increase of population and new suburbs. Americans found that this kind of food is more suitable with their lifestyles which distinguished by quick and preoccupation (Sallam, 2007). The first specialized restaurant had been established in 1921 by "Bill Engram" and "Walt Anderson" which was named "White Castle". They were characterized by efficiency, the ability to estimate or account, control, the ability to predict ad usual. They are classified according to menu, restaurant characteristics, ownership and the location (Kouzmal, 2009).

H1: There is no relation between consumer's characteristic and the type of fast-food restaurants.

\section{Consumer purchasing power and behavior \\ 2.1 Consumer purchasing power}

Purchasing power refers to the value that will be reflected by the money, which is expressed when buying an amount, number or quantities of merchandise that the consumer can purchase by his income during a particular duration of the time. This power decreases as a consequence of the income' state, if there is an expansion in the prices' level, the purchasing power will decrease and vice versa. It means that higher purchasing power depends on a higher real income since real income refers to the adjusted income for inflation. The inflation decreases the consumer's ability to purchase an amount of goods or services because of its impact on the prices' level. Therefore, the relationship between the inflation and the purchasing power is an inverse correlation (Bahmani et. al, 2017).

There are a few steps should follow to calculate the purchasing power, which established by the Bureau of Labor Statistics in United States. The calculation based on the Consumer Price Index (CPI). However, there is an opposite correlation between the CPI and the purchasing power. The following part will clarify the steps must follow to calculate the purchasing power (Leonard, 2018).

1. Placement the base year

2. Placement the target year

3. Placement the Consumer Price Index (CPI) for both of years **

By applying to the study: -

1) - The base year is 2009

2) - The target year is 2017

3) - The CPI for 2009 is 98.90 and for 2017 is 258.10

The calculation will be: $-(98.90 / 258.10) * 100=38.32 \%$

4) - Subtract the percentage you have derived from 100 to determine the percentage of change, as follows $100-38.32=61.68 \%$

This means that the purchasing power of the person which is represented in the Egyptian pound declined by $61.68 \%$ from the year 2009 to year 2017. ** 
There are some factors which influence on the purchasing power of the consumer such as; prices, income and employment, currency considerations and availability of credits.

\section{- Prices}

Refers to prices of goods and services which determinate by the government and influences by economic circumstances such as inflation. Inflation is the main enemy for the individual's purchasing power and economic development. Income, interest rates and other factors must commensurate with the increase in the prices of goods and services, in order to maintain the level of purchasing power and then making a balance in the economic society.

\section{- Income}

The standard of living and lifestyle per capita varies according to his level of income and job. So when the standard of living per capita is high, his income will be high also and as a consequence his purchasing power and luxury level also will be high and vice versa.

\footnotetext{
**Data collected from: https://tradingeconomics.com/egypt/consumer-price-index-cpi, 2018, February 25.

**Central Bank of Egypt. Statistics and Economic Reports Sector. Financial Year 2010/2011. Vol. 51 No. 4.

- Currency Considerations
}

Purchasing power influences by the variation of exchanging rates, according to other currencies. When a country imports specific goods from another country, which there is a big fluctuating between their currencies. The imported goods will be sold at a higher price than the source country. This fact does not affect the purchasing power for domestic purchases, but for imported goods only. These businesses and enterprise may load their high costs to consumers, which contributing to increase the inflation rates and diminished domestic purchasing power.

- Availability of Credit

The arrangements of banks to lend money to consumers and businesses and companies affect the total purchasing power in the same way which affects the higher income and employment levels. By the lines of credit, consumers and companies can spend more than what they actually have which giving a static and a continual boost to their personal purchasing power. Accordingly, lenders reap the benefits of credit agreements by earning interest revenues, which gives them more money to spend in the economy and also increase the gross domestic product per capita (Ingram, 2018).

\subsection{Consumer purchasing behavior}

Consumer purchasing behavior is a huge issue which threatens the economic sectors and it is distinguished by continual change. Factors which effecting the consumers' purchasing processes are social, cultural, economic, personal, political and psychological. The behavior, in general, constitutes the individuals' norms and values which are acquired from their community. The attributes that the individual acquires from his origin affected by the social factors which divided into three factors; family, reference group and roles and status (Ramya and Ali, 2016). Consumer purchasing behavior advert to a chain of coherent processes which, are done by a person or a group of people, consist of some steps such as selection, purchasing and consumption of goods and services to satisfy their needs and wants. There are many factors and characteristics of the society and also that the consumer holds as a result of growing up in this environment, which influence the identity of the person and the decisions he will make such as shopping habits, purchasing behavior and the restaurants where he goes or the food he prefers. There are different types of consumers' purchasing behaviors which constitute different types of consumer decisions like nominal, limited, extended and impulsive decision making process (Lautiainen, 2015). 


\section{Economic circumstances}

The term refers to the monetary and the financial states in a modern style. It alludes to all the economy states in a nation or region that transforms whether a scale for the budgetary furthermore benefits of the business cycles. Conditions are elements or states that assume critical piece done figuring out those result. These conditions are considered to be positive when the economy is expanding and to be negative when the economy is complicated and collapse. Economic conditions for a state are highly impacted by large number of macro and micro economic factors, including monetary and fiscal policy, the state of the global economy, unemployment levels, productivity, exchange rates, inflation, recessions etc... (Economic Conditions, 2014). For making any organization, especially restaurants, more effective and successful, understanding the consumers' conduct for buying and the economic circumstances that surrounding is a must (Sharma \& Sonwalkar, 2013). Restaurants, especially fast-food restaurants, mainly depend on the work of customers so if the economic circumstances of the country are worse, there will be a wide gap between the income of customers and the prices in markets and that will adversely affect the restaurant business and vice versa (Mansoor $\&$ Jalal, 2011). These circumstances make the consumer's behavior and purchasing decisions vary widely because they are trying to find another place that is suitable for their new economic conditions (Kar, 2010). The most important economic circumstance happened in Egypt and has huge influences on all sectors is the 25 January revolution which carries a challenging transition phase, starting out with problems such as low foreign direct investments (FDI), a high budget deficit, a high debt rate, a high unemployment rate, a huge poverty rate and a low standard of living as a result of the inflation which happened. In addition, the budget deficit is increased from $8.1 \%$ in $2009 / 10$ to $10 \%$ in $2010 / 11$. This revolution has been a transformative event, both for political and economic domains, its belongings to long lasting and wide implications throughout the Arab and the developing worlds (Abdou \& Zaazou, 2013). Unfortunately, the economy has not collected the revolution's benefits yet, because it is fallen into a horrendous crisis of economic and political instability (Hosny, Kandil \& Mohtadi, 2013).

H2: There is no relation between economic circumstances and consumer purchasing power.

\subsection{Economic factors}

It's also called financial or monetary factors; these factors refer to gathering of significant data that influence a business or an investment's value. A significant number of financial components need to be recognized when determining the present and expected future value of a business or investment portfolio. The most important economic factors that affect consumer purchasing behavior are:-

\subsubsection{Personal income}

The main responsible of establishing and determining the individual's buying conduct is the personal income. Whole personal income comprises two types; disposable and discretionary income. The first one alludes to the actual income or money remaining after deducting taxes, expenses and compulsorily deductible items from the gross income. So any expansion in the disposable income leads to an increase in the expenditure on various items and also leads to an increase in the purchasing power, behavior and vice versa. The discretionary personal income refers to the remaining balance after satisfying basic living necessities. That implies the available income purchases shopping goods, durable goods and luxuries which accurate with its amount. Any increment in the discretionary income prompts an increment in the expenditure and consumption on shopping goods, luxuries etc., which improves the standard person's living (Ramya\&Ali, 2016). 


\subsubsection{Family income}

Family income alludes to the entire income for everyone in the family. Family income is influenced by the buying behavior for the whole family not for a specific person. The surplus of family income is the remaining after the basic needs' expenditures of the family.

\subsubsection{Income expectations}

Income expectations comprise from set of ideas, thoughts and determinants about buying conduct of an individual; to understand it correctly, the study will clarify the income and expectations. There are many definitions of income, but the most popular one is that it's all the distributive transactions received by a household or families (Reich, 1991). Expectations have a significant effect in understanding how people will respond to a financial or economic crisis. These crises may make consumer expectations more pessimistic, affect their saving intentions, retirement plans, and actual financial decisions, even if the crisis has no immediate effect on their current financial situation. In other words, if the purchaser anticipates any increase in his income, he will be tempted to spend more on shopping goods, durable goods and luxuries restaurants and if he anticipated any decline in his future income or realize a financial emergency, he will strop his expenditure on comforts and luxuries facilities and services and restrict his expenditure to bare necessities (BISSONNETTE \& SOEST, 2014).

\section{$\underline{3.1 .4 \text { Savings }}$}

The biggest interest is to explain how financial literacy influences individual savings. Savings are measured as a dummy variable recorded as one if individual saved in the past 12 months. People might choose from an exhibit of products, which can be classified as formal (savings with formal financial institutions, such as a bank, MFI and rural cooperative) and informal savings (savings informal or unregistered institutions and mechanisms, for example community savings group, in jewelry or livestock), so it isn't a basic procedure (Mutsonziw, 2017).

\subsubsection{Liquid assets}

These assets allude to cash available or assets that can be easily changed to cash; it is similar to cash because it can be sold with little impact on its value. Liquid assets include cash in hand, bank balance, marketable securities, etc. If the liquid assets of an individual increase, the consumption expenditure will increase too, otherwise the increase is directed towards savings or investment funds (Nickolas, 2017).

\subsubsection{Consumer credit}

Consumer credit alludes to the account available to the consumers' longings or desires of purchasing durable comforts and luxuries. It will be available by the sellers, either directly or indirectly through banks and other financial institutions. Hire purchase, installment purchase, directs bank loans, etc. are the ways by which credit is made available to the consumers (Ramya\&Ali, 2016).

\section{Inflation Rate}

The decline of money's value means inflation or expansion. When there is an enormous gap among the consumer's income and the materials' costs furthermore services goods, especially food commodities so that the purchaser can't consume products that he used to with the same price, in that case the inflation rate is high. Also, it has enormous effects on the purchasing behavior, purchasing power and on the prosperity of the consumers and the whole community (Einarsdóttir, 2016). The rule of the government is important to secure shoppers or consumers against expansion by controlling and preventing costs from further increase to guarantee that the consumers' power for buying will not highly affected that causing some issues such as long term unemployment and poverty (Mansoor \& Jalal, 2011). Central Bank of Egypt, targeting the inflation percentages particularly in the economic openness and its vulnerability to "imported 
inflation" resulting from the increase in international prices and supported by the increment which happened in food and energy prices (Radwan, 2009).

Inflation rates in Egypt have witnessed rapid and unprecedented growth, especially after the revolution of 2011 and the events that followed it. Chart 2.1 clarifies the inflation rates that Egypt has witnessed as following:

1. Since the beginning of the millennium, inflation in Egypt has not exceeded $2 \%$ and the country has witnessed a phase of stability until 2008 it reached $18 \%$. The government tried to control this inflation and succeeded to decrease it to $11.8 \%$ in 2009 .

2. In 2010 and 2011 it reached $10.2 \%$ and $12 \%$, respectively, and stabilized at this rate in 2012.

3. In 2013 it recorded $13 \%$ and continued to rise until the central bank announced its arrival to $13.15 \%$ in 2014 and $13.36 \%$ in 2015 .

4. In the years of 2016 and 2017 inflation rates have changed markedly and taken a very serious curve, reaching $24.30 \%$ in 2016 and then continued to rise to $34.2 \%$ in 2017 , this fast also sharp rise in expansion rates might have one of its most significant causes, like the floating decision of the Egyptian pound when the Egyptian Central Bank declare the devaluation of the pound by $13 \%$ to 8.85 against the dollar (CAPMAS and CBE, 2018).

\section{Research objectives}

1. Study the effects of economic factors on the consumers' purchasing power

2. Studying the characteristics of fast-food restaurants.

3. Gain knowledge on how the purchase decision process is being made by individual consumers

\section{Methodology}

The study used desk research and field research for collecting primary data from fast food restaurants to investigate the relationships, where a random sample of customers and managers of fast food restaurants in Marsa Matruh were chosen. It can be classified as analyticaldescriptive research which giving better understanding of the relationship between economic factors and consumer purchasing power ad factors affecting them.

\section{1 sample frame}

The population of the study consisted of all local and international chains of fast food restaurants in Marsa Matrouh which are 7. The target population are customers and managers for these restaurants which using random sample for customers which are 425 customer selected by random way.

\subsection{Data Collection and measures}

To fulfills the research objectives; this study used the quantitative approach. The survey instrument was two forms of face to face questionnaire which is a type of collecting primary data. The questionnaire comprised of two sections where the first section covered the demographic data of the consumers, the second section contains questions about consumers' purchasing power and behavior. Likert scale format was used for responses which ranges from (1) strongly agree to (5) strongly disagree, after the questionnaire form was designed, it was applied on some respondents to ensure that its words are correct, terms are clear and the respondents understand it correctly in order to eliminate any misunderstanding when reading it. The questionnaire form has two main parts the first part emphasizes on understanding and 
knowing the information and personal data that serve and benefit the study which distributed to customers or managers, while the second part of customers emphasizes on knowing the most important economic which influences the individual's purchasing power and for managers emphasizes on knowing their opinions and experience in fast food restaurants and how the economic and affects these branches. The descriptive survey provides a realistic description of the purchasing power in fast food restaurants and how they have been affected by the nature of the city. Study was applied on the international and local restaurants' chains which operate in Marsa Matrouh only in summer season. The researcher was distributing the questionnaire from 1 June 2018 till 15 September 2018 to the customers of fast food restaurants. The number of distributed questionnaires was 432 customers, who've visited these restaurants; Tekka, Hardez, Kfc, Moamen, Pizza Hut, Pizza King and Mcdonald's. The number of correct surveys which collected was 425 with the response rate of $98.37 \%$. While according to restaurants' managers, questionnaires were distributed to all the managers and the number of forms was 7 with the response rate of $100 \%$.

\section{Results and discussion}

\section{Cronbach's Alfa}

Using the coefficient of reliability and honesty " Cronbach's Alfa" which is a measure used to assess the reliability, or internal consistency, of a set of scale or test items. In general, the percentage must always be more than $60 \%$ to be acceptable questionnaire form. Value for customers' questionnaires is 0.782 while for managers' questionnaires is 0.837

\section{2 questionnaire analysis}

\subsection{First part}

Results showed that fast-food restaurants are preferred by young people from 18 years to less than 30 years $(n=155,36.4 \%)$ which indicating that young people's age and rapid lifestyle affect their choices and preferences. While from 12 to less than 18years was $(n=94,22.2 \%)$ and from 30 to less than 40 was $(n=93,21.8 \%)$, these two categories showed approximate results because it considered as a transition stage from the age of young to maturity, where their preferences of food are fluctuated between fast food and traditional food. Also, females showed a high rate $(n=239,56.2 \%)$ in these restaurants when compared with males $(n=186,43.8 \%)$ where by the nature of life, males want to go to different types of places such as cafes and often do not share women going to these places with children. As for marital status, married was $(n=165,38.8 \%)$ followed by single $(n=155,36.5 \%)$. When asked about their qualifications, it was founded that $(n=177,41.6 \%)$ was secondary degree followed by university degree $(n=154,36.2 \%)$. Most of respondents hadn't additional jobs $(n=295,69.4 \%)$. The largest percentage, when they asked about the number of family members, was $(n=130,30.6 \%)$ for four members per family followed by $(n=115,27 \%)$ for three members per family. Vacationers constitute $61.2 \%$ of the total sample, whose asked about the number of days they've spent in Marsa Matrouh which was $(\mathrm{n}=130,50 \%)$ from 5 to less than 10 days and the most preferred month was August $(\mathrm{n}=120$, $46.1 \%)$. The highest proportion of income was from 3000 to less than $4500(n=150,35.3 \%)$ while the last was less than $1500(n=40,9.4 \%)$, while restaurant they preferred was MacDonald's $(n=110,25.9 \%)$ its due to respondents satisfied with its prices. 
Table 1

\begin{tabular}{|l|c|c|}
\hline \multicolumn{1}{|c|}{ Variables } & Frequency & Percentage(\%) \\
\hline Additional job & & \\
\hline Yes & 130 & $30.6 \%$ \\
\hline No & 295 & $69.4 \%$ \\
\hline Monthly income level & & \\
\hline Less than 1500 LE & 40 & $9.4 \%$ \\
\hline From 1500 to less than 3000 LE & 90 & $21.2 \%$ \\
\hline From 3000 to less than 4500 LE & 150 & $35.3 \%$ \\
\hline From 4500 LE to less than 6000LE & 60 & $14.1 \%$ \\
\hline More than 6000 & 85 & $20 \%$ \\
\hline Less than 1500 LE & 40 & $9.4 \%$ \\
\hline $\begin{array}{l}\text { The price of the meal proportional } \\
\text { with the provided portion }\end{array}$ & & \\
\hline Yes & & $30.1 \%$ \\
\hline No & 128 & $69.9 \%$ \\
\hline
\end{tabular}

**Akbar, S. (2011). Factors Affecting the Consumerâ€ ${ }^{\mathrm{TM}} \mathrm{s}$ Decision on Purchasing Power. Journal of Economics and Behavioral Studies, 2(3), 108-116.

\section{$\underline{2.2 \text { Second part }}$}

As showed in (table 2) it is the specific part about the most important reasons for selecting restaurant which the majority was (73.4\%) for consumer's income and the minority $(48.8 \%)$ for credit card acceptance. While the most event or decision that affecting their purchasing power and their expenditure levels was float of the Egyptian pound with (76\%). The general percentage in most questions exceeds $60 \%$ and standard deviation around 1 which means that there is no contrast in opinions.

Table 2

\begin{tabular}{|c|c|c|c|c|c|c|}
\hline The variable & $\begin{array}{l}\text { Likert } \\
\text { scale }\end{array}$ & Recurrences & $\begin{array}{c}\text { Percentage } \\
(\%)\end{array}$ & $\begin{array}{c}\text { Average } \\
(\boldsymbol{\mu})\end{array}$ & $\begin{array}{c}\text { Standard } \\
\text { deviation } \\
(\alpha)\end{array}$ & $\begin{array}{c}\text { General } \\
\text { percentage }\end{array}$ \\
\hline \multicolumn{7}{|c|}{ The most important factors when selecting a fast-food restaurant } \\
\hline \multirow[t]{5}{*}{$\begin{array}{l}\text { The income of } \\
\text { the consumer }\end{array}$} & $\begin{array}{c}\text { Very } \\
\text { important }\end{array}$ & 140 & $32.9 \%$ & 3.67 & 1.239 & $73.4 \%$ \\
\hline & Important & 112 & $26.4 \%$ & & & \\
\hline & Neutral & 100 & $23.5 \%$ & & & \\
\hline & $\underset{\mathrm{t}}{\text { Unimportan }}$ & 40 & $9.4 \%$ & & & \\
\hline & $\begin{array}{c}\text { Very } \\
\text { unimportant }\end{array}$ & 33 & $7.8 \%$ & & & \\
\hline \multirow[t]{5}{*}{ The price } & $\begin{array}{c}\text { Very } \\
\text { important }\end{array}$ & 144 & $33.9 \%$ & 3.56 & 1.162 & $71.2 \%$ \\
\hline & Important & 21 & $4.9 \%$ & & & \\
\hline & Neutral & 208 & $48.9 \%$ & & & \\
\hline & $\underset{\mathrm{t}}{\text { Unimportan }}$ & 29 & $6.8 \%$ & & & \\
\hline & $\begin{array}{c}\text { Very } \\
\text { unimportant }\end{array}$ & 19 & $4.5 \%$ & & & \\
\hline
\end{tabular}




\begin{tabular}{|c|c|c|c|c|c|c|}
\hline \multirow[t]{5}{*}{$\begin{array}{c}\text { The speed of } \\
\text { service }\end{array}$} & $\begin{array}{c}\text { Very } \\
\text { important }\end{array}$ & 90 & $21.2 \%$ & 3.03 & 1.414 & $60.6 \%$ \\
\hline & Important & 70 & $16.5 \%$ & & & \\
\hline & Neutral & 124 & $29.2 \%$ & & & \\
\hline & $\begin{array}{c}\text { Unimportan } \\
\mathrm{t}\end{array}$ & 100 & $2.5 \%$ & & & \\
\hline & $\begin{array}{c}\text { Very } \\
\text { unimportant }\end{array}$ & 41 & $9.6 \%$ & & & \\
\hline \multirow{5}{*}{$\begin{array}{c}\text { The } \\
\text { place/location } \\
\text { of the } \\
\text { restaurant }\end{array}$} & $\begin{array}{c}\text { Very } \\
\text { important }\end{array}$ & 68 & $16 \%$ & 3.01 & 1.387 & $60.2 \%$ \\
\hline & Important & 136 & $32 \%$ & & & \\
\hline & Neutral & 52 & $12.2 \%$ & & & \\
\hline & $\begin{array}{c}\text { Unimportan } \\
\mathrm{t}\end{array}$ & 85 & $20 \%$ & & & \\
\hline & $\begin{array}{c}\text { Very } \\
\text { unimportant }\end{array}$ & 84 & $19.8 \%$ & & & \\
\hline \multirow[t]{5}{*}{$\begin{array}{l}\text { Credit card } \\
\text { acceptance }\end{array}$} & $\begin{array}{c}\text { Very } \\
\text { important }\end{array}$ & 25 & $5.9 \%$ & 2.44 & 1.146 & $48.8 \%$ \\
\hline & Important & 51 & $12 \%$ & & & \\
\hline & Neutral & 112 & $26.4 \%$ & & & \\
\hline & $\underset{\mathrm{t}}{\text { Unimportan }}$ & 137 & $32.2 \%$ & & & \\
\hline & $\begin{array}{c}\text { Very } \\
\text { unimportant }\end{array}$ & 100 & $23.5 \%$ & & & \\
\hline \multicolumn{7}{|c|}{ Indicators for your acceptance with these statements } \\
\hline \multirow{5}{*}{$\begin{array}{l}\text { Egyptian } \\
\text { revolution } \\
2011\end{array}$} & $\begin{array}{l}\text { Strongly } \\
\text { affect }\end{array}$ & 92 & $21.6 \%$ & 3.30 & 1.334 & $66 \%$ \\
\hline & Affect & 140 & $32.9 \%$ & & & \\
\hline & Neutral & 47 & $11.1 \%$ & & & \\
\hline & $\begin{array}{c}\text { Doesn't } \\
\text { affect }\end{array}$ & 99 & $23.3 \%$ & & & \\
\hline & $\begin{array}{l}\text { Doesn't } \\
\text { strongly } \\
\text { affect }\end{array}$ & 47 & $11.1 \%$ & & & \\
\hline \multirow{5}{*}{$\begin{array}{l}\text { Float of the } \\
\text { Egyptian } \\
\text { pound }\end{array}$} & $\begin{array}{c}\text { Strongly } \\
\text { affect }\end{array}$ & 150 & $35.3 \%$ & 3.80 & 1.159 & $76 \%$ \\
\hline & Affect & 131 & $30.8 \%$ & & & \\
\hline & Neutral & 65 & $15.3 \%$ & & & \\
\hline & $\begin{array}{l}\text { Doesn't } \\
\text { affect }\end{array}$ & 68 & $16 \%$ & & & \\
\hline & $\begin{array}{l}\text { doesn't } \\
\text { strongly } \\
\text { affect } \\
\end{array}$ & 11 & $2.6 \%$ & & & \\
\hline
\end{tabular}




\begin{tabular}{|c|c|c|c|c|c|c|}
\hline $\begin{array}{c}\text { The increase of } \\
\text { the dollar }\end{array}$ & $\begin{array}{c}\text { Strongly } \\
\text { affect }\end{array}$ & 160 & $37.6 \%$ & 3.76 & 1.236 & $75.2 \%$ \\
\cline { 2 - 7 } & Affect & 120 & $28.2 \%$ & & & \\
\cline { 2 - 7 } & Neutral & 45 & $10.6 \%$ & & & \\
\cline { 2 - 7 } & $\begin{array}{c}\text { Doesn't } \\
\text { affect }\end{array}$ & 87 & $20.5 \%$ & & & \\
\cline { 2 - 7 } & $\begin{array}{c}\text { Doesn't } \\
\text { strongly } \\
\text { affect }\end{array}$ & 13 & $3.1 \%$ & & & \\
\hline
\end{tabular}

**Alam, M. D. (2015). Factors that Influence the decision when buying second-hand products. Umeå School of Business and Economics (USBE).

**Lautiainen, T. (2015). Factors affecting consumers' buying decision in the selection of a coffee brand. Faculty of Business Administration, Lappeenranta

\section{Discussion and Findings}

The study seeks to clarify and investigate the relationship between economic factors and customer purchasing power. Also, clarify characteristics for customers who going to fast food restaurants. Results showed that the most important factor when selecting a fast-food restaurant is consumers' income followed by menu prices. That is agreed with the study of (Nguyen and Gizaw, 2014) which refereed to the sensitivity of consumers toward prices. Whereas prices constitute their purchasing power and behavior. There is a slight difference between income and price which mean that their average is convergent and they almost have the same importance because they are depending on each other and when income increase the power increased too. This is agreed with (Bahmani, 2017, p. 463-483) who pointed that purchasing power decreases as a consequence of the income state, if there is an expansion in the prices' level without any increase in income, the purchasing power will decrease and vice versa. It means that higher purchasing power depending on a higher real income. Also, the study refers to the economic fluctuations which highly influenced the customers' purchasing power like float of the Egyptian pound which is the most affecting factor that made a wide gap between the Egyptian Pound and Dollar which influences the prices of all goods and services. That confirmed with the study of (Einarsdóttir, 2016) and (Radwan, 2009) which refer to the devaluation means higher import prices of food, and various commodities, the high cost of fuel and the local industrial production, resulting in increasing the inflation rates which is actually happened in Egypt after the implementation of this condition and the devaluation of the Egyptian pound at the end of December 2012. The study founded that restaurants' customers sharing with each other in many characteristics such as ages, social segmentation that leads also to the same income segmentation and all of them have the same food preferences. These finding agreed with the study of (Kouzmal, 2009, Chapter 2.p.5-10) that clarifies there is a significant relationship between customers' characteristics and the type of food as a fast-food restaurant.

\section{Conclusion}

As previously discussed, the major aim of the study is to investigate the relationship between economic factors which represented in two elements; customer's income \& menu prices and customer purchasing power. Also, to study and clarify the main characteristics of customers whose prefer going to this type of restaurants. economic factors are strongly associated with consumers' purchasing behavior. The differentiations in Exchange rate impacted on the purchasing power of consumers which was a result of the float the Egyptian pound's decision. 
This decision led prices rise to unprecedented increase and was affecting their living conditions as a whole and also the raw materials of food. This inflation prompts to create a recession, which resulted in the manifestation of five distinctive types of consumers with different behaviors they; a demand for simplicity, discretionary thrift, mercurial consumption, green consumerism and ethical consumerism. Customer purchasing power declined by $61.68 \%$ because of the inflation rates expansion.

\section{Limitation and Future research}

The limitations of this study are related to the nature of conducting a comprehensive review of a field of literature because The sample is constrained by chosen search protocols and by library availability of selected journals and issue years. Also, the results cannot be generalized to the residents of Marsa Matrouh, as the sample included visitors to restaurants without distinguishing between visitor and resident. As for future researches, it is recommended to take larger sample where it is possible to emerge new relationships and other factors. Also, applying the study in more than one country to study the consumer personality and consumer behavior according to the nature of the city. Also, Studies about the economic situation of the country must carry out and making a comparison or evaluation between the exiting economic programs and suggestions to make other programs to adjustment the present economic way as an endeavor to decrease this terrible disparity in exchange rates and price rise of the Egyptian pound. Finally, examining the different situations of the consumers which happened as a consequence of economic conditions comprehensively and design programs or ways to deal with them to recover from this condition and return back to their usual shopping behavior without any fear from the future. 


\section{REFERENCES}

Abdou, P., Salman, D., \& Zaazou, Z. (2013). "The Egyptian Revolution and post Socioeconomic impact". Topics in Middle Eastern and African Economies. Vol. 15, No. 1,. May

Astuti, R., Silalahi, R. L. R., \& Wijaya, G. D. P. (2015). "Marketing Strategy Based on Marketing Mix Influence on Purchasing Decisions of Malang Apples Consumers at Giant Olympic Garden Mall (MOG), Malang City, East Java Province, Indonesia". Agriculture and Agricultural Science Procedia, 3, 67-71.

Bahmani-Oskooee, M., Chang, T., Chen, T. H., \& Tzeng, H. W. (2017). "Revisiting purchasing power parity in Eastern European countries: quantile unit root tests". Empirical Economics, 52(2), 463-483 .

Bissonnette, L., \& Van Soest, A. (2014). "The Financial Crisis and Consumers' Income and Pension Expectations ."

Capello, R. (Ed.).(2017)."Seminal Studies in Regional and Urban Economics: Contributions from an Impressive Mind". Springer .

Central Bank of Egypt. Statistics and Economic Reports Sector. FY 2010/2011. Vol. 51 No. 4.

"Economic Conditions". Retrieved from https://www.investopedia.com/terms/e/economicconditions.asp. (2017, November 19).

Einarsdóttir, H. (2016). "The impact of economics crisis on buying behavior and consumer attitudes". Thesis. Reykjavik University. School of business .

Emilia Reis. (2015). "INFLUENCING FACTORS ON CONSUMER BUYING BEHAVIOUR OF LUXURY GOODS". Bachelor's thesis. International Business .

Furaiji, F., Łatuszyńska, M., \& Wawrzyniak, A. (2012). "An empirical study of the factors influencing consumer behaviour in the electric appliances market ."

Hosny, A., Kandil, M., \& Mohtadi, H. "The Egyptian Economy Post-Revolution: Sectoral Diagnosis of Potential Strengths and Binding Constraints". In Economic Research Forum, Working paper (No. 767). (2013, September).

Kar, M. (2010). "Consumer behaviour over the last 25 years". The Retail Digest, 46-53 .

Lautiainen, T. (2015)."Factors affecting consumers' buying decision in the selection of a coffee brand". Saimaa University of Applied Sciences, Faculty of Business Administration, Lappeenranta, Degree Programme in International Business .

MOHSIN KHAN and Elsa Miler. (2017, July 21). "High rates of inflation in Egypt. Rafic ElHariri Center for the Middle East". Retrieved from http://www.achariricenter.org/inflation-is-so-high-in-egypt-ar ./

Murendo, C., \& Mutsonziwa, K. (2017)."Financial literacy and savings decisions by adult financial consumers in Zimbabwe". International Journal of Consumer Studies, 41(1), 95 103 . 
N Ramya and Dr. SA Mohamed Ali. (2016) ."Factors affecting consumer buying behavior". International Journal of Applied Research. P. 76-80 .

Orji, O. G. (2013). "Major Classic Consumer Buying Behaviour Models: Implications for Marketing Decision-Making". Journal of Economics and Sustainable Development, 4(4), 164-173.

Reich, U. P. (1991)."Concept and definition of income in the national accounts. Review of Income and Wealth", 37(3), 235-247 .

Sharaf, M. F. (2015). "Inflation and Inflation Uncertainty Revisited: Evidence from Egypt". Economies, 3(3), 128-146 .

Sharma, V., Sonwalkar, J., \& Kapse, M. (2013)."Consumer purchase behaviour for green product". Nepalese Academy of Managementjga, 1(1), 95-110 .

Tomczak, T., Reinecke, S., \& Kuss, A. (2017)."Strategic Marketing: Market-oriented Corporate and Business Unit Planning". Springer .

Waqar Nisar. (2014(. "Influences of Consumer Behavior: Research about Beverage Brands of Pakistan". International Journal of Academic Research in Business and Social Sciences. DOI: 10.6007/IJARBSS/v4-i8/1080. August (2014). 